\title{
UPAYA PENINGKATAN MOTIVASI KERJA PADA PERUSAHAAN JASA KONTRUKSI MELALUI PENDEKATAN TEORI KEBUTUHAN MASLOW
}

\author{
Sri Handayani ${ }^{1}$ \\ ${ }^{1}$ Prodi Magister Manajemen, Pascasarjana Universitas Muhammadiyah Yogyakarta \\ Email: handayani@gmail.com \\ Siswoyo Haryono ${ }^{2}$ \\ ${ }^{2}$ Prodi Doktor Manajemen, Pascasarjana Universitas Muhammadiyah Yogyakarta \\ Email:profsis12@gmail.com \\ Fauziah $^{3}$ \\ ${ }^{3}$ Prodi Doktor Manajemen, Pascasarjana Universitas Muhammadiyah Yogyakarta \\ Email: Fauziyah_umy@yahoo.com
}

\begin{abstract}
This study aims to identify efforts to increase work motivation and the characteristics of Maslow's needs dimensions implemented in the construction services company members of GAPANSI (Association of All Indonesia Construction Implementers) Kebumen Regency. This type of descriptive research with a questionnaire as a source of data. The population is all employees of the Construction Services Company Members of GAPENSI (Joint Construction Executors of Indonesia) Kebumen Regency totaling 167 employees. The research sample of 44 employees, using a purposive sampling technique that is the sampling technique that is given a limit as sampling from the population in accordance with the research objectives. Data testing techniques using computer software in the form of SPSS include validity test with bivariate correlation between each indicator with the total construct score on the questionnaire with a significance value of less than 0.05, reliability test with Alpha Cronbach with minimum correlation coefficient conditions 0.6. Based on the validity test all variables have a $p$ value $<\square 0.05$ so that it is declared valid and can be further processed. The reliability test results showed that the alpha cronbach's physiological needs were 0.842 , security feeling 0.861, Social 0.730, appreciation 0.871 and self-actualization 0.905. Because the Cronbach's alpha values obtained are $>0.6$. This proves that each variable has high reliability or has good consistency as a measurement tool. Associated with the results of the analysis of the description of the respondents showed that the work motivation of employees in the top priority in all categories shows the social needs while the difference in mean the highest value obtained on the needs of awards.
\end{abstract}

Keywords: Motivation, Work, needs characteristics and Maslow's Needs Theory

Abstrak: Penelitian ini bertujuan untuk mengidentifikasi upaya peningkatan motivasi kerja yang dilakukan dan karakteristik dimensi kebutuhan Maslow diimplementasikan pada perusahaan jasa kontruksi anggota GAPANSI (Gabungan Pelaksana Konstruksi Seluruh Indonesia) Kabupaten Kebumen. Jenis penelitian deskriptif dengan kuesioner sebagai sumber data. Populasi adalah seluruh karyawan Perusahaan Jasa Kontruksi Anggota GAPENSI (Gabungan Pelaksana Konstruksi Seluruh Indonesia) Kabupaten Kebumen berjumlah 167 karyawan. Sampel penelitian sebanyak 44 karyawan, menggunakan teknik purposive sampling yaitu teknik sampling yang diberi batasan sebagai penarikan sampel dari populasi sesuai dengan tujuan penelitian. Teknik pengujian data menggunakan bantuan software komputer berupa SPSS meliputi uji validitas dengan korelasi bivariate antara masing - masing indikator dengan total skor konstruk pada kuesioner dengan nilai signifikansi kurang dari 0,05, uji reliabilitas dengan Alpha Cronbach dengan syarat minimum koefisien korelasi 0,6 . Berdasarkan uji validitas seluruh variabel memiliki $p$ value $<\alpha 0,05$ sehingga dinyatakan valid dan dapat diproses lebih lanjut. Hasil uji reliabilitas menunjukkan bahwa nilai

Sri Handayani ${ }^{1}$, Siswoyo Haryono ${ }^{2}$, Fauziah ${ }^{3}$ - Upaya Peningkatan Motivasi Kerja Pada Perusahaan Jasa Kontruksi Melalui ... [Vol 11, No 1 (2020): April 2020] JBTI 
alpha cronbach's kebutuhan fisologis 0.842 , rasa aman 0.861 , Sosial 0.730 , penghargaan 0.871 dan aktualisasi diri 0.905 . Karena nilai alpha cronbach's yang didapat masing-masing > 0.6. Hal ini membuktikan tiap variabel memiliki reliabilitas yang tinggi atau memiliki konsistensi yang baik sebagai alat ukur. Berkaitan dengan hasil Analisis deskripsi responden menunjukan bahwa motivasi kerja karyawan secara prioritas utama pada semua kategori menunjukan pada kebutuhan sosial sedangkan secara selisih mean nilai tertinggi diperoleh pada kebutuhan penghargaan.

Kata Kunci: Motivasi, Kerja, karakteristik kebutuhan dan Teori Kebutuhan Maslow.

Article History: Received 2020-03-07; Revised 2020-04-08; Accepted 2020-04-13

\section{PENDAHULUAN}

Indonesia merupakan negara kaya dengan Sumber Daya Alam (SDA). Kekayaan tersebut jika dikelola dengan baik, bukan tidak mungkin menjadikan Indonesia negara yang perokonomiannya patut diperhitungkan serta memiliki daya saing yang luar biasa. Salah satu kunci untuk meningkatkan daya saing adalah peningkatan produktivitas, salah satunya adalah produktivitas SDM. Produktivitas SDM memiliki peran dominan dalam upaya peningkatan daya saing organisasi. Manajemen SDM adalah ilmu dan seni mengelola dan mengembangkan unsur manusia berupa cipta, rasa dan karsa sebagai aset organisasi, demi terwujudnya tujuan organisasi dengan cara memperoleh, mengembangkan, dan memelihara tenaga kerja secara efektif dan efesien. Persoalan yang ada adalah bagaimana meningkatkan kinerja sumber daya manusia yang optimal sehingga tujuan organsiasi tercapai. Dalam upaya meningkatkan kualitas, produktivitas dan kinerja sumber daya manusia yang bermuara pada kualitas sumberdaya manusia tangguh dan berdaya saing tinggi, terdapat banyak aspek yang harus dikaji. Salah satu faktor yang sangat menentukan keberhasilan pelaksanaan suatu proyek konstruksi adalah sumberdaya. Tanpa sumberdaya, mustahil suatu proyek dapat dilaksanakan. Proyek yang besar secara otomatis memerlukan sumberdaya yang besar pula. Mengingat sangat berpengaruhnya sumberdaya, terutama sumberdaya manusia dalam pelaksanaan suatu proyek maka diperlukan pengelolaan proyek yang baik, yang dapat menciptakan strategi yang tepat, yang dapat menentukan bagaimana agar setiap sumber daya manusia dalam organisasi proyek memberi kontribusi secara optimal terhadap pencapaian tujuan proyek.

Dalam pembangunan nasional, jasa konstruksi mempunyai peranan penting dan strategis mengingat jasa konstruksi menghasilkan produk akhir berupa bangunan atau bentuk fisik lainnya, baik yang berupa prasarana maupun sarana yang berfungsi mendukung pertumbuhan dan perkembangan berbagai bidang, terutama bidang ekonomi, sosial, dan budaya untuk mewujudkan masyarakat adil dan makmur yang merata materiil dan spiritual berdasarkan Pancasila dan UndangUndang Dasar 1945. Selain berperan mendukung berbagai bidang pembangunan, jasa konstruksi berperan pula untuk mendukung tumbuh dan berkembangnya berbagai industri barang dan jasa yang diperlukan dalam penyelenggaraan pekerjaan konstruksi. Oleh karena itu, jasa konstruksi nasional diharapkan semakin mampu mengembangkan perannya dalam pembangunan nasional melalui peningkatan keandalan yang didukung oleh struktur usaha yang kokoh dan mampu mewujudkan hasil pekerjaan konstruksi yang berkualitas.

GAPENSI (Gabungan Pelaksana Konstruksi Seluruh Indonesia), dalam pengklasifikasian kontraktor menurut Lembaga Kebijakan Pengadaan Barang/Jasa Pemerintahan, terdapat 7 tingkatan. Tingkat satu adalah kontraktor perorangan dan belum berbadan hukum, Tingkat 2-4 masuk kategori kontraktor kecil yang hanya boleh menggarap proyek dengan nilai maksimal Rp 2,5 miliar, sedangkan tingkat 5-7 tergolong kontraktor non kecil yang bisa mengerjakan proyek yang nilainya di atas Rp 2,5 miliar (Ketua Umum Gapensi, Jawa Tengah, Oryxahadi, 2012). Ditengah ketatnya kondisi persaingan bisnis jasa konstruksi ini, para pelaku bisnis jasa konstruksi di Indonesia berupaya keras untuk menjaga kelangsungan hidup perusahaannya. Terjaganya eksistensi suatu perusahaan diantaranya tergantung pada kemampuan perusahaan tersebut untuk melihat peluang-peluang pasar yang ada. Dalam kondisi seperti ini, bidang pemasaran perusahaan

Sri Handayani ${ }^{1}$, Siswoyo Haryono ${ }^{2}$, Fauziah ${ }^{3}$ - Upaya Peningkatan Motivasi Kerja Pada Perusahaan Jasa Kontruksi Melalui ... [Vol 11, No 1 (2020): April 2020] JBTI 
memegang peranan yang sangat penting dalam hal melihat peluang-peluang pasar yang ada. Bidang pemasaran ini memiliki kontak paling besar dengan lingkungan eksternal perusahaan. Tidak saja berfungsi untuk melihat peluang pasar, namun secara keseluruhan bidang pemasaran difungsikan untuk memenangkan ketatnya persaingan pasar. kontraktor percaya bahwa bagian terpenting dari suatu organisasi adalah bagian produksi, sehingga mereka lebih berorientasi pada produksi dibandingkan dengan pemasaran.

Dari 134 perusahaan, domisili perusahaan paling banyak terkonsentrasi di kota Gombong dan Kebumen, sebagian lagi menyebar mulai dari Bonorowo, Prembun, Kutowinangun, Pejagoan, Sruweng, Petanahan, Karanganyar bahkan sampai Ayah. Kecamatan yang tidak mencatatkan anggotanya di GAPENSI diantaranya adalah kecamatan Padureso, Poncowarno, Buluspesantren, Karangsambung, Sadang, Karanggayam, Rowokele dan Buayan. Di Kabupaten Kebumen dalam hal ini pemerintah daerah selaku Pengguna Barang dan Jasa sudah mengarahkan para jasa konstruksi dalam hal ini kontraktor untuk bekerja secara profesional, karena bagaimanapun juga kontraktor merupakan mitra kerja pemerintah daerah untuk penyedia barang dan jasa konstruksi. Sehingga kontraktor yang ada di Kabupaten Kebumen benar-benar harus memperhatikan Motivasi dan Kepuasan kerja karyawannya.

Motivasi kerja karyawan berkaitan erat dengan manajeman sumber daya manusia, karyawan yang memiliki motivasi tinggi dalam bekerja mempunyai etos kerja yang bagus atau bekerja dengan penuh semangat, optimisme dan senantiasa terpancar citra positif dalam dirinya. Motivasi kerja sebagian ditentukan oleh kebutuhan dan kebutuhan ini mempengaruhi tingkat kepuasan kerja. Setiap manusia mempunyai needs (kebutuhan, dorongan, intrinsic dan extrinsic faktor), yang pemunculannya sangat tergantung dari kepentingan individu. Maslow dalam Siagian (2002) membuat needs hierarchy theory untuk menjawab tentang tingkatan kebutuhan manusia tersebut. Kebutuhan manusia diklasifikasi menjadi lima hierarki kebutuhan yaitu: (1) Kebutuhan Fisiologis, (2) Kebutuhan Rasa Aman, (3) Kebutuhan Sosial, (4) Kebutuhan akan Harga Diri, dan (5) Aktualisasi Diri.

Kepuasan kerja muncul dari pekerjaan yang menarik, karyawan yang bekerja dengan sungguh-sungguh memberikan perhatian dan menyukai pekerjaan tersebut. Sehingga banyak praktisi meyakini bahwa kepuasan kerja akan meningkatkan kinerja karyawan. Karyawan yang mempunyai tingkat kepuasan kerja rendah akan mengakibatkan sikap negatif atau tidak menyukai pekerjaannya. Hal ini akan mengakibatkan tingginya tingkat kemangkiran kerja, rendahnya kerjasama antar karyawan membahayakan organisasi karena menghambat tercapainya visi, misi dan tujuan organisasi Siagian, (2002). Keberhasilan organisasi sangat ditentukan oleh kuantitas dan kualitas karyawan yang dapat mempengarui kualitas kerja. Pimpinan harus mampu memberikan dorongan motivasi yang tepat serta memperlakukan karyawan sebagai manusia seutuhnya, sehingga mereka akan merasa puas dan bekerja dengan baik. Kinerja sebagai output pekerjaan dapat dilihat sejauhmana karyawan dapat memberikan pelayanan secara prima. Di Kabupaten Kebumen para pelaku jasa konstruksi khususnya kontraktor masih belum memperhatikan motivasi kerja karyawannya hal ini dapat diperhatikan dalam pelaksanaan suatu proyek masih banyak kontraktor yang bekerja tidak tepat waktu dan tepat mutu. Faktor kepuasan kerja karyawan merupakan hal yang dapat menjadi tolak ukur bahwa dengan terpenuhinya kebutuhan karyawan maka karyawan dapat menyelesaikan pekerjaannya dengan maksimal.

Pada penelitian terdahulu terdapat beberapa studi yang membahas tentang penerapan teori hierari kebutuhan Abraham Maslow, diantaranya oleh: Artaya (2019), Sari Elisa dkk (2018), Iskandar (2016), dimana pada umumnya hasil penelitian mereka mengatakan bahwa motivasi berdasarkan hierarki kebutuhan Maslow yang meliputi kebutuhan fisiologis, rasa aman, sosial, penghargaan, dan aktualisasi diri berpengaruh terhadap kinerja karyawan.

Muhammad Hengki Setiawan ${ }^{1}$, Prayekti ${ }^{2}$, I.Soni Kurniawan ${ }^{3}$ - Faktor Yang Mepengaruhi Organizational Citizenship Behavior ... [Vol 11, No 1 (2020): April 2020] JBTI 


\section{KAJIAN TEORI \\ Motivasi Kerja}

Kata motivasi (motivation) berasal dari bahasa latin movere, kata dasarnya adalah motif (motive) yang berarti dorongan, sebab atau alasan seseorang melakukan sesuatu. Sementara itu Gibson dalam Suwarto (2010) mendefinisikan motivasi adalah suatu konsep yang menguraikan tentang kekuatan-kekuatan yang ada dalam diri karyawan yang memulai dan menggerakkan perilaku. Sedangkan Mahesa (2010) motivasi kerja adalah dorongan yang membuat karyawan melakukan sesuatu dengan cara untuk mencapai tujuan tertentu. Tidak ada keberhasilan melakukan sesuatu, seperti mengelola karyawan, tanpa adanya motivasi baik dari manajer maupun dari karyawan. Sementara itu Martoyo (2007) mendefinisikan motivasi kerja sebagai sesuatu yang menimbulkan dorongan atau semangat kerja atau dengan kata lain pendorong semangat kerja. Dengan dorongan dimaksudkan agar dapat memberikan desakan yang alami untuk memuaskan kebutuhan-kebutuhan hidup, dan merupakan kecenderungan untuk mempertahankan hidup. Dengan demikian dapatlah dikatakan bahwa "motivasi" pada dasarnya adalah kondisi mental seseorang yang mendorong dilakukannya suatu tindakan dan memberikan kekuatan yang mengarah kepada pencapaian tujuan, kebutuhan, memberi kepuasan ataupun mengurangi ketidakseimbangan (Martoyo, 2007).

Motivasi terbentuk dari kebutuhan manusia dan pada dasarnya seseorang terlebih dahulu harus mengetahui apa yang diinginkan dan dibutuhkan sehingga nantinya dapat mengatur rencana untuk mencapainya. Manusia berusaha untuk memuaskan kebutuhannya dan mereka memahami bahwa untuk memenuhi tujuan tersebut harus ada keinginan yang sangat kuat untuk mencapainya. Dalam pencapaian tujuan tersebut dibutuhkan suatu usaha dalam mengembangkan pengetahuan, keterampilan, keahlian dan kemampuan untuk mencapainya. Apabila usaha tersebut berhasil, maka kebutuhan akan menjadi kurang kuat dan motivasi juga akan berkurang. Kegiatan tersebut dapat dikatakan sebagai proses terjadinya motivasi yang ada di dalam diri seseorang (Usmara, 2006).

Suwarto (2010) faktor-faktor yang mempengaruhi motivasi kerja, diantaranya: (1) teknis organisasi, (2) struktur sosial, (3) kemauan untuk menyelesaikan tugas, (4) imbalan yang diterima dari bekerja, (5) dapat diterima karyawan sebagai anggota kelompok. Gomez dalam Muniroh (2013) aspek-aspek yang terdapat pada motivasi kerja terdiri dari dua aspek, yaitu: aspek individu, dan aspek organisasional. Aspek individu terdiri dari kebutuhan-kebutuhan (needs), tujuan-tujuan (goals), dan kemampuan (abilities). Sedangkan aspek organisasional terdiri dari pembayaran (pay), keamanan kerja (job security), rekan kerja (co-workers), pengawasan (supervisor), pujian (praise), dan pekerjaan itu sendiri (job it self).

Teori motivasi yang dikembangkan oleh Maslow mengemukakan bahwa kebutuhan manusia itu dapat diklasifikasikan ke dalam lima hirarki kebutuhan, yaitu sebagai berikut (Greenberg dalam Sutrisno, 2009): (1) Kebutuhan Fisiologis (Phisiological Needs), (2) Kebutuhan akan Rasa Aman (Safety Needs) (3) Kebutuhan Sosial (Social Needs) (4) Kebutuhan akan Penghargaan (Esteem Needs), dan (5) Kebutuhan Aktualisasi Diri (Self Actualization).

\section{Kepuasan Kerja}

Mangkunegara (2007) kepuasan kerja adalah suatu perasaan yang menyokong atau tidak menyokong diri pegawai berhubungan dengan pekerjaan maupun dengan kondisi dirinya. Hariandja (2005) kepuasan kerja adalah sejauh mana individu merasakan secara positif atau negatif berbagai macam faktor atau dimensi dari tugas-tugas dalam pekerjaannya. Menurut As'ad (2004) faktorfaktor yang mempengaruhi kepuasan kerja antara lain: (a) Faktor Psikologi, merupakan faktor yang berhubungan dengan kejiwaan karyawan, yang meliputi minat, keterampilan kerja, sikap kerja, bakat \& keterampilan, (b) Faktor Sosial, merupakan faktor yang berhubungan dengan interaksi sosial baik antara sesama karyawan dengan atasannya/dengan karyawan yang berbeda jenis pekerjaannya, (c) Faktor Fisik Financial, merupakan faktor yang berhubungan dengan kondisi fisik lingkungan kerja\&kondisi fisik karyawan, meliputi jenis pekerjaan, waktu kerja \& istirahat,

Sri Handayani ${ }^{1}$, Siswoyo Haryono ${ }^{2}$, Fauziah ${ }^{3}$ - Upaya Peningkatan Motivasi Kerja Pada Perusahaan Jasa Kontruksi Melalui ... [Vol 11, No 1 (2020): April 2020] JBTI 
perlengkapan kerja, keadaan ruang, suhu, penerangan, pertukaran udara, kondisi kesehatan karyawan, umur \& sebagainya.

Menurut Hariandja (2005), faktor yang mempengaruhi kepuasan kerja adalah: (1) Gaji. Yaitu jumlah bayaran yang diterima seseorang sebagai akibat dari pelaksanaan kerja apakah sesuai dengan kebutuhan dan dirasakan adil, (2) Pekerjaan itu sendiri. Yaitu Isi pekerjaan yang dilakukan seseorang apakah memiliki elemen yang memuaskan, (3) Rekan sekerja. Yaitu teman-teman kepada siapa seseorang senantiasa berinteraksi dalam pelaksanaan pekerjaan seseorang dapat merasakan rekan kerjanya sangat menyenangkan/tidak menyenangkan, (4) Atasan. Yaitu seseorang yang senantiasa memberi perintah/petunjuk dalam pelaksanaan kerja. Cara-cara atasan dapat tidak menyenangkan bagi seseorang menyenangkan dan hal ini dapat mempengaruhi kepuasan kerja, (5) Promosi. Yaitu kemungkinan seseorang dapat berkembang melalui kenaikan jabatan. Seseorang dapat merasakan adanya kemungkinan yang besar untuk naik jabatan/tidak. Proses kenaikan jabatan kurang terbuka, ini juga dapat mempengaruhi tingkat kepuasan kerja karyawan, (6) Lingkungan Kerja. Yaitu Lingkungan Fisik \& Psikologis. Untuk meningkatkan kepuasan kerja karyawan, perusahaan harus merespon kebutuhan pegawai dan hal ini sekali lagi secara tidak langsung telah dilakukan pada berbagai kegiatan manajemen sumber daya manusia seperti dijelaskan sebelumnya. Namun demikian, tindakan lain masih perlu dilakukan dengan cara yang disebut peningkatan kualitas kehidupan kerja. Dalam beberapa definisi terlihat bahwa kepuasan kerja merupakan perasaan pekerja (karyawan) terhadap pekerjaannya. Perasaan itu mencerminkan dari persesuaian antara apa yang diharapkan karyawan dengan apa yang didapatkan karyawan dari pekerjaannya. Dari definisi di atas, akhirnya dapat diambil suatu garis besar pengertian bahwa kepuasan kerja adalah pandangan karyawan terhadap pekerjaannya, mencakup perasaan karyawan \& penilaian karyawan terhadap peranan pekerjaan dalam pemenuhan kebutuhannnya.

\section{Kinerja}

Menurut Pasolong (2010) kinerja merupakan hasil kerja secara kualitas dan kuantitas yang dicapai oleh seseorang dalam melaksanakan fungsinya sesuai dengan tanggungjawab yang diberikan kepadanya. Sementara itu Harsuko (2011) kinerja adalah hasil kerja yang dicapai seseorang atau kelompok orang dalam suatu perusahaan sesuai dengan wewenang dan tanggungjawab masing-masing dalam upaya pencapaian tujuan perusahaan secara legal, tidak melanggar hukum dan tidak bertentanga dengan moral dan etika. Kinerja adalah sejauh mana seseorang telah memainkan perannya dalam melaksanakan strategi organisasi, baik dalam mencapai sasaran khusus yang berhubungan dengan peran perorangan dengan memperlihatkan kompetensi yang relevan bagi organisasi. Kinerja adalah konsep yang multi dimensional mencakup tigas aspek yaitu: sikap (attitude), kemampuan (ability), dan prestasi (accomplishment).

Sinambela (2012) mengemukakan kinerja pegawai didefinisikan sebagai kemampuan pegawai dalam melakukan suatu keahlian tertentu. Kinerja pegawai sangat diperlukan, karena kinerja pegawai akan diketahui dari seberapa jauh kemampuan pegawai dalam melaksanakan tugas yang dibebankan kepadanya. Untuk itu diperlukan penentuan kriteria yang jelas dan terukur serta ditetapkan secara bersama-sama yang dijadikan sebagai acuan.

Menurut Bernardin dan Russell dalam Riani (2011) kriteria yang digunakan untuk menilai kinerja karyawan adalah: (1) quantity of work, (2) quality of work, (3) job knowledge, (4) creativeness, (5) cooperation, (6) dependability, (7) initiative, (8) personal qualities. Steers dalam Cahyono (2005) faktor-faktor yang mempengaruhi kinerja diantaranya: (1) kemampuan, kepribadian dan minat kerja, (2) kejelasan dan penerimaan atau kejelasan peran seorang pekerja yang merupakan taraf pengertian dan penerimaan seseorang atas tugas yang diberikan kepadanya, (3) tingkat motivasi pekerja, yaitu daya energy yang mendorong mengarahkan dan mempertahankan perilaku. 


\section{METODE PENELITIAN}

Obyek penelitian ini adalah Perusahaan-perusahaan Jasa Kontruksi Anggota Gapensi Kabupaten Kebumen. Sedangkan subyek dalam penelitian ini adalah karyawan Perusahaan Jasa Kontruksi Anggota Gapensi Kabupaten Kebumen yang berjumlah 43 orang. Metode penelitian yang digunakan adalah penelitian deskriptif kualitatif. Penelitian kualitatif adalah suatu penelitian yang ditunjukkan untuk mendeskripsikan dan menganalisis fenomena, peristiwa, aktivitas sosial, sikap, kepercayaan, persepsi, pemikiran, orang secara individual atau kelompok. Metode deskriptif merupakan suatu metode penelitian yang ditujukan untuk menggambarkan fenomena-fenomena yang ada yang berlangsung saat ini atau saat yang lampau. Alasan menggunakan metode deskriptif karena untuk mendapatkan gambaran sistematis, faktual dan akurat, mengenai fakta-fakta upaya peningkatan motivasi kerja pada perusahaan jasa kontruksi melalui pendekatan teori Maslow. Untuk menunjang penelitian ini, digunakan metode pengukuran analisis instrument Skala Likert. Untuk menguji kualitas instrument digunakan uji validitas dan uji reliabilitas. Sedangkan pengujian secara deskriptif dan pengujian hipotesis penelitian digunakan alat bantu program komputer SPSS versi 22.0. Pengukuran Variabel dalam penelitian ini dapat dilihat dalam tabel 1. Sebagai berikut:

Tabel 1. Pengukuran Variabel Penelitian

\begin{tabular}{|l|l|}
\hline \multicolumn{1}{|c|}{ Dimensi } & \multicolumn{1}{c|}{ Indikator } \\
\hline $\begin{array}{l}\text { Kebutuhan Fisiologis } \\
\text { kebutuhan untuk mempertahankan hidup dari kematian }\end{array}$ & $\begin{array}{l}\text { • Pangan } \\
\text { - Sandang } \\
\text { Papan } \\
\text { Kesehatan } \\
\text { Pendidikan }\end{array}$ \\
\hline $\begin{array}{l}\text { Kebutuhan akan Rasa Aman } \\
\text { keselamatan dan keamanan diri dan harta bendanya }\end{array}$ & $\begin{array}{l}\bullet \text { Fisik } \\
\text { Non fisik }\end{array}$ \\
\hline $\begin{array}{l}\text { Kebutuhan Sosial } \\
\text { kebutuhan untuk hidup bersama dengan orang lain }\end{array}$ & $\begin{array}{l}\text { Kebersamaan dan } \\
\text { Kasih sayang }\end{array}$ \\
\hline $\begin{array}{l}\text { Kebutuhan akan Penghargaan } \\
\text { adanya penghargaan diri dan penghargaan prestise diri dari lingkungannya }\end{array}$ & $\bullet$ Materi \\
\hline $\begin{array}{l}\text { Kebutuhan Aktualisasi Diri } \\
\text { memperlihatkan kemampuan dirinya secara optimal (jenjang karir) }\end{array}$ & $\bullet$ Potensi diri \\
\hline
\end{tabular}

\section{HASIL DAN PEMBAHASAN}

\section{Upaya Peningkatan Motivasi Kerja ditinjau dari perspektif Teori Kebutuhan Maslow.}

Upaya Peningkatan Motivasi Kerja ditinjau dari perspektif Teori Kebutuhan Maslow pada Perusahaan Jasa Kontruksi Anggota GAPENSI, Kabupaten Kebumen dapat dijelaskan dengan beberapa faktor. Berdasarkan hasil penelitian diketahui bahwa dari teori kebutuhan Maslow kebutuhan fisiologis, rasa aman, sosial, penghargaan dan aktualisasi diri secara prioritas utama dapat dilihat pada tabel berikut:

Tabel 2. Skala Prioritas Kebutuhan karyawan

\begin{tabular}{|c|c|}
\hline Kategori & Prioritas Kebutuhan \\
\hline Jenis Kelamin & Kebutuhan Sosial \\
\hline Umur & Kebutuhan Sosial \\
\hline Pendidikan & Kebutuhan Sosial \\
\hline Masa Kerja & Kebutuhan Aktualisasi Diri \\
\hline
\end{tabular}

Sri Handayani ${ }^{l}$, Siswoyo Haryono ${ }^{2}$, Fauziah $^{3}$ - Upaya Peningkatan Motivasi Kerja Pada Perusahaan Jasa Kontruksi Melalui ... [Vol 11, No 1 (2020): April 2020] JBTI 
Berdasarkan tabel di atas diketahui bahwa pada tiga kategori menunjukan pada kebutuhan sosial, sedangkan kebutuhan sosial yang ada pada GAPENSI Kabupaten Kebumen antara lain kebersamaan dan kekeluargaan, solidaritas antar karyawan, banyak teman, keharmonisan, keakraban, berkumpul, bos sangat sayang, dan rasa persaudaraan. Berikutnya berdasarkan selisih nilai mean diperoleh nilai tertinggi untuk masing-masing kategori sebagai berikut:

Tabel 3. Selisih mean pada masing-masing kebutuhan

\begin{tabular}{|c|c|}
\hline Kebutuhan & Selisih Mean Tertinngi \\
\hline Kebutuhan fisiologis & 0,900 \\
\hline Kebutuhan rasa aman & 1,600 \\
\hline Kebutuhan sosial & 0,600 \\
\hline Kebutuhan penghargaan & 2,100 \\
\hline Kebutuhan aktualisasi diri & 0,838 \\
\hline
\end{tabular}

Berdasarkan selisih mean pada masing-masing kebutuhan diperoleh hasil selisih mean paling tinggi pada kebutuhan penghargaan yaitu sebesar 2,100. Hal ini menunjukan bahwa kebutuhan penghargaan pada karyawan anggota GAPENSI Kabupaten Kebumen lebih bervariasi atau beragam dibanding dengan kebutuhan lainnya. Sebagian responden memerlukan penghargaan yang tinggi atas hasil kerjanya, dan sebagian lagi mungkin tidak terlalu mementingkan penghargaan tersebut. Perlakuan GAPENSI Kabupaten Kebumen pada karyawannya dalam memberikan penghargaan berupa bonus, kesejahteraan, reward, ucapan selamat, refreshing tiap akhir tahun memberikan inventaris kendaraan, dan intensif. Dengan adanya penghargaan yang diberikan, karyawan GAPENSI Kabupaten Kebumen merasa dihargai dan menjadi semangat dalam bekerja. Penelitian oleh Yasmeen, Umar Farooq, dan Fahaq Asghar (2013) menunjukkan pengaruh secara langsung antara variabel penghargaan terhadap kinerja karyawan yang ditunjukkan dalam bentuk penghargaan non materiil memiliki pengaruh yang lebih besar dibandingkan penghargaan materiil untuk meningkatkan kinerja karyawannya.

\section{Karakteristik Dimensi Kebutuhan Maslow}

Berdasarkan hasil olah data kuesioner terhadap karyawan GAPENSI Kabupaten Kebumen Implementasi Karakteristik dimensi kebutuhan Maslow dapat dilihat pada tabel berikut.

Tabel 4. Karakteristik Kebutuhan

\begin{tabular}{|c|c|c|c|c|c|c|c|c|c|c|c|c|}
\hline \multirow{3}{*}{ Kebutuhan } & \multicolumn{12}{|c|}{ Kategori } \\
\hline & \multicolumn{2}{|c|}{ Jenis Kelamin } & \multicolumn{4}{|c|}{ Umur } & \multicolumn{3}{|c|}{ Pendidikan } & \multicolumn{3}{|c|}{ Masa Kerja } \\
\hline & LK & $\mathbf{P}$ & 21-30 & $31-40$ & 41-50 & $51-60$ & SMP & SLTA & D3/S1 & $<=5$ & 6-10 & $>=11$ \\
\hline Kebutuhan fisiologis & 3.180 & 3.183 & 3,278 & 3,567 & 3,900 & 3,000 & 3,533 & 3,310 & 3,720 & 3,264 & 3,600 & 3,133 \\
\hline Kebutuhan rasa aman & 3.340 & 2.967 & 3.174 & 3.644 & 4.000 & 2.400 & 3,400 & 3,206 & 3,940 & 3,143 & 3,860 & 3,067 \\
\hline Kebutuhan sosial & 3.360 & 3.542 & 3.765 & 3.644 & 3.600 & 3,600 & 3,600 & 3,645 & 3,920 & 3,693 & 3,700 & 3,100 \\
\hline Kebutuhan penghargaan & 3.190 & 2.892 & 2.991 & 3.533 & 3,900 & 1,800 & 3,000 & 3,052 & 3,840 & 3,093 & 3,520 & 2,767 \\
\hline Kebutuhan aktualisasi diri & 3.300 & 2.944 & 3.174 & 3.537 & 3,500 & 3,000 & 3,333 & 3,129 & 3,967 & 3,179 & 3,667 & 2,833 \\
\hline
\end{tabular}

Berdasarkan tabel di atas diperoleh karakteristik kebutuhan karyawan GAPENSI Kabupaten Kebumen sebagai berikut:

a. Kebutuhan fisiologis berupa kebutuhan dasar hidup antara lain makan, pakaian, rumah, sekolah, kesehatan. Berdasarkan kategori responden kebutuhan fisiologis tertinggi terdapat pada jenis kelamin perempuan, umur 41 - 50 tahun, dengan pendidikan D3/S1 dan masa kerja 6-10 tahun.

b. Kebutuhan rasa aman berupa tempat kerja yang nyaman, dekat dengan rumah dan adanya jaminan hari tua. Berdasarkan kategori responden kebutuhan rasa aman tertinggi terdapat pada

Muhammad Hengki Setiawan ${ }^{1}$, Prayekti ${ }^{2}$, I.Soni Kurniawan ${ }^{3}$ - Faktor Yang Mepengaruhi Organizational Citizenship Behavior ...

[Vol 11, No 1 (2020): April 2020] JBTI 
jenis kelamin laki-laki, umur 41 - 50 tahun, dengan pendidikan D3/S1 dan masa kerja 6 - 10 tahun.

c. Kebutuhan sosial berupa kebersamaan dan kekeluargaan, solidaritas antar karyawan, bisa berkumpul, bercanda, sifat kekeluargaan, keharmonisan, keakraban, kekeluargaan dan kekompakan, kekeluargaan yang erat, rasa persaudaraan yang baik. Berdasarkan kategori responden kebutuhan sosial tertinggi terdapat jenis kelamin perempuan, umur $21-30$ tahun, dengan pendidikan D3/S1 dan masa kerja 6-10 tahun.

d. Kebutuhan penghargaan berupa bonus, kesejahteraan, reward, ucapan selamat, refreshing tiap akhir tahun memberikan inventaris kendaraan, dan insensif, umroh dan naik haji. Berdasarkan kategori responden kebutuhan penghargaan tertinggi terdapat pada jenis kelamin laki-laki, umur 41 - 50 tahun, dengan pendidikan D3/S1 dan masa kerja 6 - 10 tahun.

e. Kebutuhan aktualisasi diri berupa menimba/menambah ilmu, jadi direktur utama perusahaan, bekerja sesuai dengan jurusan yang diambil, training keahlian khusus, mengikuti seminarseminar di luar perusahaan. Berdasarkan kategori responden kebutuhan penghargaan tertinggi terdapat pada jenis kelamin laki-laki, umur 31 - 40 tahun, dengan pendidikan D3/S1 dan masa kerja 6 - 10 tahun.

\section{KESIMPULAN DAN SARAN}

Berdasarkan hasil analisis data serta pembahasan, penelitian mendukung beberapa penelitian terdahulu yang dilakukan oleh Artaya (2019), Sari Elisa dkk (2018), Iskandar (2016), dimana motivasi kerja karyawan GAPENSI Kabupaten Kebumen yang menjadi prioritas utama adalah kebutuhan sosial, untuk itu GAPENSI Kabupaten Kebumen perlu lebih memperhatikan kegiatankegiatan yang mendukung untuk kebutuhan sosial diantaranya tersedianya forum komunikasi dan pertemuan, Peningkatan efektifitas komunikasi lembaga ditingkat nasional, dan meningkatkan tali persaudaraan untuk karyawan. Adapun karakteristik dimensi kebutuhan Maslow yang ditemukan dalam penelitian ini adalah: (a) kebutuhan fisiologis terdapat pada jenis kelamin perempuan, umur 41 s.d 50 tahun, pendidikan D3/S1 dan masa kerja 6 s.d 10 tahun, (b) kebutuhan rasa aman terdapat pada jenis kelamin laki-laki, umur 41 s.d 50 tahun, pendidikan D3/S1 dan masa kerja 6 s.d 10 tahun, (c) kebutuhan sosial terdapat pada jenis kelamin perempuan, umur 21 s.d 30 tahun, pendidikan D3/S1 dan masa kerja 6 s.d 10 tahun, (d) kebutuhan penghargaan terdapat pada jenis kelamin lakilaki, umur 41 s.d 50 tahun, pendidikan D3/S1 dan masa kerja 6 s.d 10 tahun, dan (e) kebutuhan aktualisasi diri terdapat pada jenis kelamin laki-laki, umur 31 s.d 40 tahun, pendidikan D3/S1 dan masa kerja 6 s.d 10 tahun.

Berdasarkan hasil penelitian, pembahasan, dan kesimpulan, maka saran yang dapat diberikan adalah sebagai berikut. Bagi Perusahaan disarankan untuk memberikan proritas pada motivasi kerja karyawan GAPENSI Kabupaten Kebumen berupa kebutuhan sosial, maka sebaiknya lebih memperhatikan lagi pada kegitan-kegiatan yang mendukung terpenuhinya kebutuhan sosial tersebut. Sebagai contoh adanya arisan/perkumpulan antar karyawan, rekreasi bersama keluarga karyawan, seminar atau pelatihan karyawan sampai tingkat nasional, serta terbentuknya forum karyawan. Bagi peneliti selanjutnya disarankan untuk dapat mengembangkan penelitian ini dengan menambahkan sampel dan wawancara untuk memdapatkan hasil yang lebih mendalam, mengembangkan penelitian dengan teori-teori kebutuhan yang lain. Dalam penelitian ini upayaupaya kebutuhan yang dapat mempengaruhi motivasi kerja karyawan secara prioritas utama adalah kebutuhan sosial. Dari hasil penelitian ini yang masih perlu di teliti oleh peneliti selanjutnya pada upaya peningkatan kebutuhan aktualisasi diri, sehingga dapat mempengaruhi dan memberikan kontribusi terhadap motivasi kerja karyawan lebih baik

Sri Handayani ${ }^{1}$, Siswoyo Haryono ${ }^{2}$, Fauziah $^{3}$ - Upaya Peningkatan Motivasi Kerja Pada Perusahaan Jasa Kontruksi Melalui ... [Vol 11, No 1 (2020): April 2020] JBTI 


\section{DAFTAR PUSTAKA}

Artaya, I Putu, 2019. Penerapan Teori Motivasi Hierarki Kebutuhan Abraham Maslow dan Teori Motivasi Pemeliharaan Hezberg Dalam Menciptakan Loyalitas Pekerja. Researchgate. Januari.

Akusita, Eny. 2001. Pengaruh Karakteristik Dan Faktor Kondisi Pekerjaan Dengan Kepuasan Kerja Perawat Puskesmas di Kabupaten Pati. Tesis. Universitas Diponegoro. Dipublikasikan.

Almigo, Nuzsep, 2004. Hubungan Antara Kepuasan Kerja dengan Hubungan Produktivitas Kerja Karyawan, Fakultas Psikologi Universitas Bina Darma,Palembang. Vol 1 No 1, pp. 50-60.

As'ad. 2004. Psikologi Industri. Yogyakarta: Liberty

Brahmasari Ida Ayu, Agus Suprayetno. 2008. Pengaruh Motivasi Kerja, Kepemimpinan dan Budaya Organisasi Terhadap Kepuasan Kerja Karyawanserta Dampaknya pada Kinerja Perusahaan (Studi kasus pada PT. Pei HaiInternational Wiratama Indonesia). Pasca Sarjana Universitas 17 Agustus Surabaya Jurnal Manajemen Dan Kewirausahaan, Vol 10, No 2, SEPTEMBER 2008: hal.124-135.

Cahyono, Budhi dan Suharto, 2005. Pengaruh Budaya Organisasi, Kepemimpinan dan Motivasi Kerja terhadap Kinerja Sumber Daya Manusia di Sekretariat DPRD Propinsi Jawa Tengah, Jurnal JRBI, Vol. 1, Yogyakarta.

Dirianzani Leindra, Sugiono, Dewi Hardiningtyas. 2014. Analisis Pengaruh Motivasi Intrinsik dan Ekstrinsik Terhadap Kinerja Karyawan Borongan dengan Komitmen Organisasi Sebagai Mediasi. Studi kasus: Perusahaan Rokok Adi Bungsu Malang. Jurnal Rekayasa dan Manajemen Sistem Industri. Teknik Industri Universitas Brawijaya. Vol. 2 no 5. Hal 11241135.

Ekaningsih, Ana Sari. 2012. Pengaruh Motivasi Kerja terhadap Kinerja dengan Persepsi Lingkungan Kerja sebagai Pemoderasi. Pada Satuan Polisi PamongPraja. Kota Surakarta. Journal Sciocienta Kopertis Wilayah XI Kalimantan. Vol 4, No 1. pp. 19-30.

Hariandja, Marihot Tua Efendi, 2007. Manajemen Sumber Daya Manusia: Pengadaan, Pengembangan, Pengkompensasian, dan Peningkatan Produktivitas Pegawai. Jakarta: Grasindo.

Harsuko, Riniwati, 2011. Mendongkrak Motivasi dan Kinerja: Pendekatan Pemberdayaan SDM. Malang: UB Press.

Iskandar, 2016. Implementasi Teori Hirarki Kebutuhan Abraham Maslow terhadap Peningkatan Kinerja Pustakawan. Khizanah Al-Hikmah, Vol. 4 No. 1 Januari-Juni.

Koesmono H.Teman. 2005 Pengaruh Budaya Organisasi Terhadap Motivasi Dan Kepuasan Kerja Serta Kinerja Karyawan Pada Sub Sektor Industri Pengolahan Kayu Skala Menengah di Jawa Timur. Jurusan Ekonomi Manajemen. Fakultas Ekonomi - Universitas Kristen Petra. Jurnal Manajemen \& Kewirausahaan, Vol. 7. No. 2. 171-188.

Mahesa, D. 2010. Analisis Pengaruh Motivasi dan Kepuasan Kerja terhadap Kinerja Karyawan dengan Lama Kerja sebagai Variabel Moderating (Studi pada PT. Coca Cola Amatil Indonesia (Central Java). Semarang: Universitas Diponegoro.

Mangkunegara, Anwar Prabu, 2007, Manajemen Sumber Daya Manusia Perusahaan, PT. Remaja Rosdakarya, Bandung.

Martoyo, Susilo, 2007, Manajemen Sumber Daya Manusia, BPFE Yogyakarta.

Murty, Hary., Veronika Agustini Srimulyani. 2013. Pengaruh Motivasi terhadap Kinerja Karyawan PDAM Kota Madiun. Journal Riset Manajemen dan Akutansi. Vol 1, No 1.pp. 1017.

Pasolong, Harbani, 2010. Teori Administrasi Publik. Bandung: Alfabeta

Riani Laksmi Asri, 2011. Perspektif Kompensasi. Surakarta: Yuma Pustaka.

Sari Elisa, dan Dwiarti Rina, 2018. Pendekatan Hierarki Abraham Maslow pada Prestasi Kerja Karyawan PT. Madubaru (PG Madukismo Yogyakarta). JPSB, Vol. 6 No. 1.

Siagian, Sondang P, 2002. Kiat Meningkatkan Produktivitas Kerja. Jakarta: Rineka Cipta.

Muhammad Hengki Setiawan ${ }^{1}$, Prayekti ${ }^{2}$, I.Soni Kurniawan ${ }^{3}$ - Faktor Yang Mepengaruhi Organizational Citizenship Behavior ...

[Vol 11, No 1 (2020): April 2020] JBTI 
Sinambela, Lijan Poltak, 2012. Kinerja Pegawai. Yogyakarta: Graha Ilmu.

Sutrisno, Edi. 2009. Manajemen Sumber Daya Manusia, Edisi Pertama, Jakarta: Kencana Prenada Media Group.

Suwarto, 2010. Perilaku Keorganisasian. Yogyakarta: Universitas Atma Jaya

Usmara, A. 2006. Motivasi Kerja : Proses, Teori, dan Praktik. Amara Books. Yogyakarta.

Sri Handayani ${ }^{1}$, Siswoyo Haryono ${ }^{2}$, Fauziah ${ }^{3}$ - Upaya Peningkatan Motivasi Kerja Pada Perusahaan Jasa Kontruksi Melalui ... [Vol 11, No 1 (2020): April 2020] JBTI 